\title{
An approach towards sustainable energy performance by green building: a review of current features, benefits and barriers
}

\author{
Molla Shahadat Hossain Lipu ${ }^{1, *}$, Taskin Jamal², Tahia Fahrin Karim \\ ${ }^{1}$ Dept. of EEE, University of Asia Pacific (UAP), Dhaka, Bangladesh \\ ${ }^{2}$ Dept. of EEE, American International University-Bangladesh (AIUB), Dhaka, Bangladesh \\ ${ }^{3}$ Dept. of EEE, Primeasia University, Dhaka, Bangladesh
}

\section{Email address:}

lipuhossain@gmail.com(M. S. H. Lipu), taskinjamal@gmail.com(T. Jamal), fahrinkarim@yahoo.com(T. F. Karim)

To cite this article:

Molla Shahadat Hossain Lipu, Taskin Jamal, Tahia Fahrin Karim. An Approach towards Sustainable Energy Performance by Green Building: A Review of Current Features, Benefits and Barriers. International Journal of Renewable and Sustainable Energy. Vol. 2, No. 4, 2013, pp. 180-190. doi: 10.11648/j.ijrse.20130204.18

\begin{abstract}
Buildings are estimated to account for more than a third of the world's resources in construction, 40 percent of global energy (including embodied energy), 12 percent of fresh water use, and generate 40 percent of greenhouse gases (GHGs) emissions and make up 40 percent of waste to landfill. The worldwide concerns for the impending resource crunch and the dangers of global warming, and the understanding of the role that buildings can play to contribute positively to the economy, energy security, human health and the environment have led to a quiet green building revolution around the globe over the last decade. Energy plays a vital role over the life cycle of a building, hence sustainable buildings and energy refurbishments in buildings hold enormous potential for energy saving and a reduction of greenhouse gas emissions. The main target of this paper is to find out the effectiveness and sustainability in green building design implementations which evaluates energy performances. In addition, the paper explains the key feature of the green building as well as its usefulness, current challenges and barriers.
\end{abstract}

Keywords: Green Buildings, Sustainable Energy Performance, Renewable Energy, Energy Efficiency, GHG Emission

\section{Introduction}

The world's urban population has now reached to 3.2 billion where the rate of growth is much higher in less-developed countries. Building sector accounts for about one-fifth of the world's total delivered energy consumption which includes both residential and commercial buildings. Buildings are estimated to account for more than a third of the world's resources in construction, 40 percent of global energy (including embodied energy), 12 percent of fresh water use, and generate 40 percent of greenhouse gas (GHG) emissions and make up 40 percent of waste to landfill [1]. The annual growth of building sector energy consumption was $52.8 \mathrm{EJ}$ in 2007 , which is projected to reach $72.8 \mathrm{EJ}$ in 2035 [2]. Nevertheless, countries of Asia and the Pacific region are facing unprecedented financial and environmental challenges in their pursuit of achieving rapid growth and the Millennium Development Goals (MDGs).
The lower and middle income countries in Asia and the Pacific may be in different stages of development, but they are all urbanizing rapidly and feel the pressure to create adequate infrastructure in order to cope with the growing demand for housing, industries, transportation and other services. Asian cities are home to more people than all the urban dwellers in the rest of the world. In China, for example, urbanites use almost double the energy per capita as the national average [3]. Besides, the building stock in China is estimated to be 35 billion $\mathrm{m}^{2}$. Moreover, nearly 2 billion $\mathrm{m}^{2}$ of floor space are likely to be added every year by 2020, representing almost half of the global total [4]. In addition, buildings account for 42 percent of the total energy use in China. In 2005, end-use energy consumption in the building sector shows that heating, ventilation and air conditioning accounts for 45 percent, followed by water heating (19 percent), appliances (14 percent) and lighting (10 percent) $[5,6]$. 


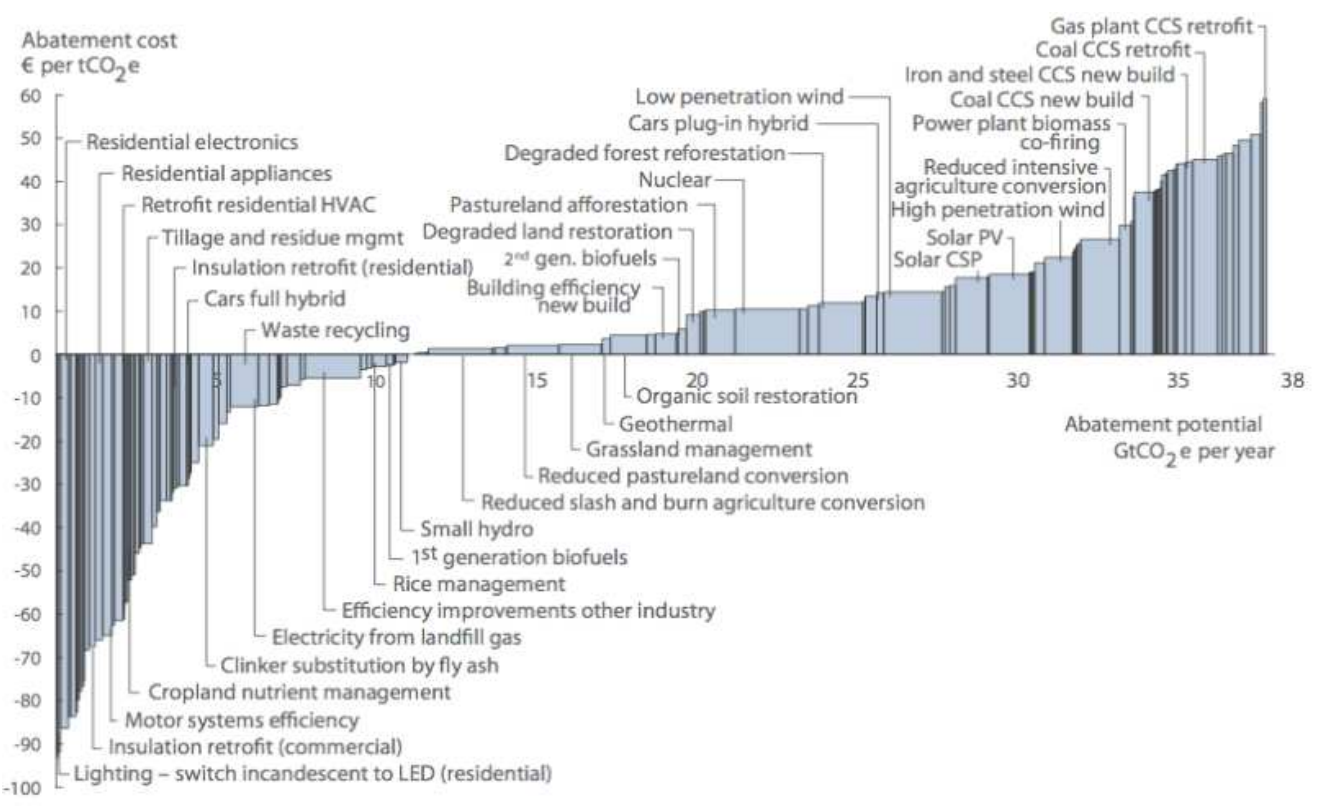

Figure1. Global GHG Abatement Curve for the Building Sector (scenario perspective 2030)

There are three major factors influencing the growth of energy use in buildings: demographic evolution (population growth), socio-cultural changes (nuclear families, lifestyle changes), and design of buildings and equipment (energy use per unit building area). In industrialized countries, appliances accounted for only $16 \%$ of the household energy in 1990 , but its share had grown to $21 \%$ by 2005 , despite of increased appliance efficiency [3]. Buildings are estimated to be worth US\$7.5 trillion per year, contributing to approximately 10 percent of global GDP [7]. There are several issues [8] which has driven the building sector towards sustainable practices which include increasing scarcity of natural resources, population growth, extreme weather phenomena, growing awareness of environmental issues, legislation on environmental issues in building codes, increasing interest in human health and wellbeing aspects, rapid and continuous urbanization, aging population in industrialized countries, a rise of living standards in developing countries, rapid development of ICT solutions. Moreover, Buildings create direct employment for over 111 million people around the world, with 75 percent in developing countries and 90 percent in micro firms [9].

The building energy efficiency, the thermal performance of buildings and the material efficiency are considered as significant parameters of sustainable energy performance indicators to be fully taken into consideration during the performance evaluations [10]. According to the study by Joelsson [11], with a view of the effectiveness of green buildings towards decreasing the use of energy and its negative impacts on the environment, there are fundamental strategies, including 'reducing the energy demands', 'enhanced energy efficiency' and 'application of passive design techniques'. Likewise, the utilization of appropriate building envelopes is influential in more than half of the embodied energy distribution in a building, particularly in residential buildings [12].
Climate change and $\mathrm{CO}_{2}$ emissions are a major challenge because a wide range of predicted environmental changes associated with climate change will have a direct or indirect impact on the building industry. Directly, the building industry will incur higher operational costs associated with rising energy, water and management costs. Along with the building operating costs, construction and demolition costs will also increase due to rising oil prices and transportation costs, as well as increasing landfill charges. Buildings can however play a major proactive role in our fight against climate change. Green buildings have the potential to not only reduce pressure on infrastructure and $\mathrm{CO}_{2}$ emissions, but also contribute to the improvement of the air quality, social welfare and enhanced energy security. IPCC 2007 estimated that around 30 percent of the baseline $\mathrm{CO}_{2}$ emissions in buildings projected for 2020 could be avoided cost-effectively by the use of various technological options, resulting in a number of co-benefits such as decreased air pollution, better health and reduced mortality, improved social welfare and energy security [2]. Sustainable energy performances can be achieved by green buildings, which is holding some of the most profitable means of abating climate change. According to McKinsey [13], an international consulting firm, carbon emissions in the building sector can be reduced substantially, either with net economic benefits or at low cost, using a range of proven technologies aimed at demand reduction and energy efficiency. The Global greenhouse gas abatement cost curve for the building sector shows that changes in building design and construction could offset up to 6 billion tonnes of carbon emissions annually through measures with a zero or negative net life-cycle cost (see also the global GHG abatement cost curve in Figure 1). In other words, green buildings have the potential to save money and carbon emissions at the same time through effective insulation, glazing, water heating, air conditioning, lighting, and other energy-efficiency measures. 


\section{Key Features of a Green Building}

A green building incorporates design techniques, materials and technologies that minimize its overall impacts on the environment and human health which can be achieved by sustainable design, material selection, construction, maintenance, removal, and possible reuse. Main outcomes are minimum site disruption, reduced fossil fuel use, lower water consumption, and fewer pollutants used and released during construction, occupation and disposal of the building [14]. Building a green building is not just a matter of assembling a collection of the latest green technologies or materials. Rather, it is a process in which every element of the design is first optimized and then the impact and interrelationship of various different elements and systems within the building and site are re-evaluated, integrated, and optimized as part of a whole building solution. For example, interrelationships between the building site, site features, the path of the sun, and the location and orientation of the building and elements such as windows and external shading devices have a significant impact on the quality and the effectiveness of natural day lighting. These elements also affect direct solar loads and overall energy performance for the life of the building. Without considering these issues early in the design process, the design is not fully optimized and the result is likely to be a very inefficient building. Green buildings are associated with some key features which give the unique architectural design characteristics that are missing in traditional construction. These include sustainable site design; water conservation and quality; energy and environment; indoor environmental quality; and conservation of materials and resources.

\subsection{Sustainable Site Design}

Sustainable design incorporates the minimize urban sprawl and needless destruction of valuable land, habitat and green space, which results from inefficient low-density development. The design also concentrates on the higher density urban development, urban re-development and urban renewal, and brownfield development as a means to preserve valuable green space. Besides, the sustainable design also preserves key environmental assets through a careful examination of each site along with put emphasis on design and construction process that minimizes site disturbance which preserves and actually restores or regenerates valuable habitat, green space and associated eco-systems that are vital to sustaining life. Some aspect should be taken into consideration to achieve better comfort and lower the energy bill include landscaping, building orientation, building form, building fabric, air infiltration, natural delighting and ventilation and passive solar heating and cooling.

\subsection{Water Quality and Conservation}

Managing of water and the waste from the beginning of the construction period until demolition is an important feature of a green building. This feature follows the hydrological systems where the existing natural water is recycled. Emphasis should be placed on retention of storm water and on-site infiltration and ground water recharge using methods that closely emulate natural systems. One of the significant features of this design is to minimize the unnecessary and inefficient use of potable water on the site while maximizing recycling and reuse of water, including harvested rainwater, storm water, and gray water.

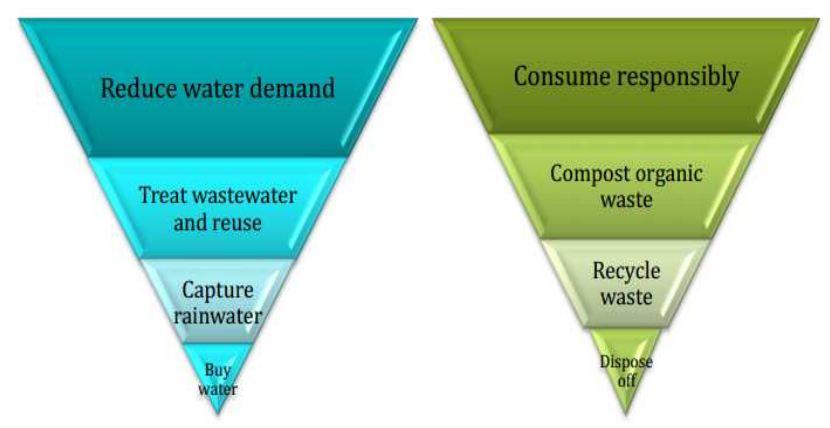

Figure2. Strategy to Manage Water, Wastewater and Solid Waste in Green Buildings [14]

\subsection{Energy and the Environment}

To achieve sustainable development, Energy conservation and environmental protection are essential. One of the main aims of a green building is to minimize adverse impacts on the environment (air, water, land, natural resources) through optimized building siting, optimized building design, material selection, and aggressive use of energy conservation measures. Figure 3 depicts how buildings can be designed to minimize their dependence on fossil forms of energy, lower their operating costs, create a healthier environment for their occupants and contribute to the fight against climate change, without necessarily incurring high total cost.

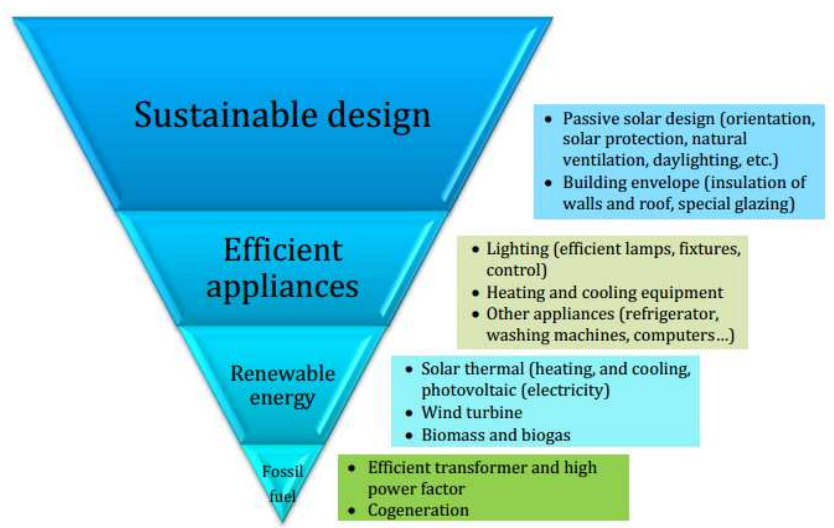

Figure3. Strategy to design a building to minimize its dependence on fossil energy [14]

The major strategies and technologies for energy conservation and environment protection include: optimize passive solar orientation, use of external shading devices, optimize building orientation, massing, shape, design, and 
interior colors and finishes, use high performance low-e glazing, optimize the value of exterior insulation and the overall thermal performance of the exterior envelope assembly, use energy efficient t-8 and t-5 bulbs, high efficiency electronic ballasts, and lighting controls, use state-of-the art, high efficiency heating, ventilation and air conditioning (HVAC) and plumbing equipment, chillers, boilers, and water heaters, etc., avoid the use of HCFC and Halon based refrigeration, cooling and fire suppression systems, use energy star certified energy efficient appliances, office equipment, lighting and HVAC systems and consider on-site small-scale wind, solar, and/or fuel cell based energy generation and co-generation.

\subsection{Indoor Environmental Quality}

Green building focuses healthy, comfortable and productive indoor environment for building occupants and visitors. Green buildings are designed to create a healthy, pleasant and productive work environment which offer the best possible conditions in terms of indoor air quality, ventilation, thermal comfort, access to natural ventilation and day lighting, and effective control of the acoustical environment. The technologies which is used to fulfill this criteria include material selection, maximize the use of natural day lighting, maximize the use of operable windows and natural ventilation, design building envelope and environmental systems in such a way that not only treat air temperature and provide adequate ventilation, but also respect all of the environmental conditions which affect human thermal comfort and health, including the mean radiant temperature of interior surfaces, indoor air humidity, indoor air velocity, and indoor air temperature.

\subsection{Material and Resources}

Green building involves establishing construction to minimize the use of non-renewable construction materials and other resources such as energy and water through efficient engineering, design, planning and construction and effective recycling of construction debris as well as to maximize the use of recycled content materials, modern resource efficient engineered materials, and resource efficient composite type structural systems wherever possible. This feature integrates the maximum use of re-usable, renewable, sustainably managed, bio-based materials along with identifying the ways to reduce the amount of materials used and reduce the amount of waste generated through the implementation of a construction waste reduction plan. One of the biggest positive impacts on the environment is to prevent and recycle waste which has a reduced depletion of natural resources such as trees, oil and minerals, lower from manufacturing and transportation, lessen the demand for energy and water compared to virgin material manufacturing processes, and reduced the greenhouse gas emissions due to lower demand for energy in manufacturing and transportation. One of the studies carried out in Sweden where buildings were constructed with recycled materials which reduced the environmental impacts by 45 percent in comparison with those using all new materials [15]. Besides, a significant amount of energy ( 12 percent to 40 percent) can be saved if recycled materials are used for building construction [16].

\section{Sustainable Energy Performance in Green Buildings}

The concept of sustainability is a broad global issue where various studies about people, the environment and society are correlated [17]. This sustainability represents a new approach which holds the concepts of 'green infrastructure', encompasses three fundamental constituents as environmental, socio-cultural and economic sustainability represented in Figure 4 [17, 18]. Sustainability of built environments is recognized as a holistic approach to the adaptation of environmental, economic and socio-cultural concerns in the design and built evolution of architecture.

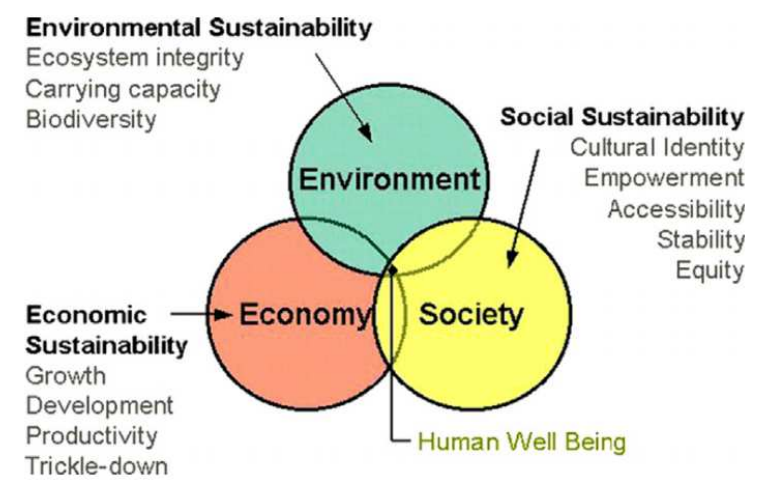

Figure4. The Basis of Sustainable Developments

As the concern has been raised now-a-days on global warming, climate change and the incompatibility of natural resources and energy demand due to the depletion of energy resources, the consideration of natural resources and energy conservation has become a global issue. In line with the environmental issues, different studies have been carried focusing on the concepts of energy maintenance, efficiency and conservation, embodied energy and renewable energy resources, leading to the concept of the green sustainable built environment $[19,20]$. In order to arise sustainability concept in green building, it is important to pay sufficient attention to the sustainable construction of green buildings. Thereby, the sustainable construction criteria must be introduced to the architects and developers in order to be used in the entire cycle of the construction process of green buildings. 


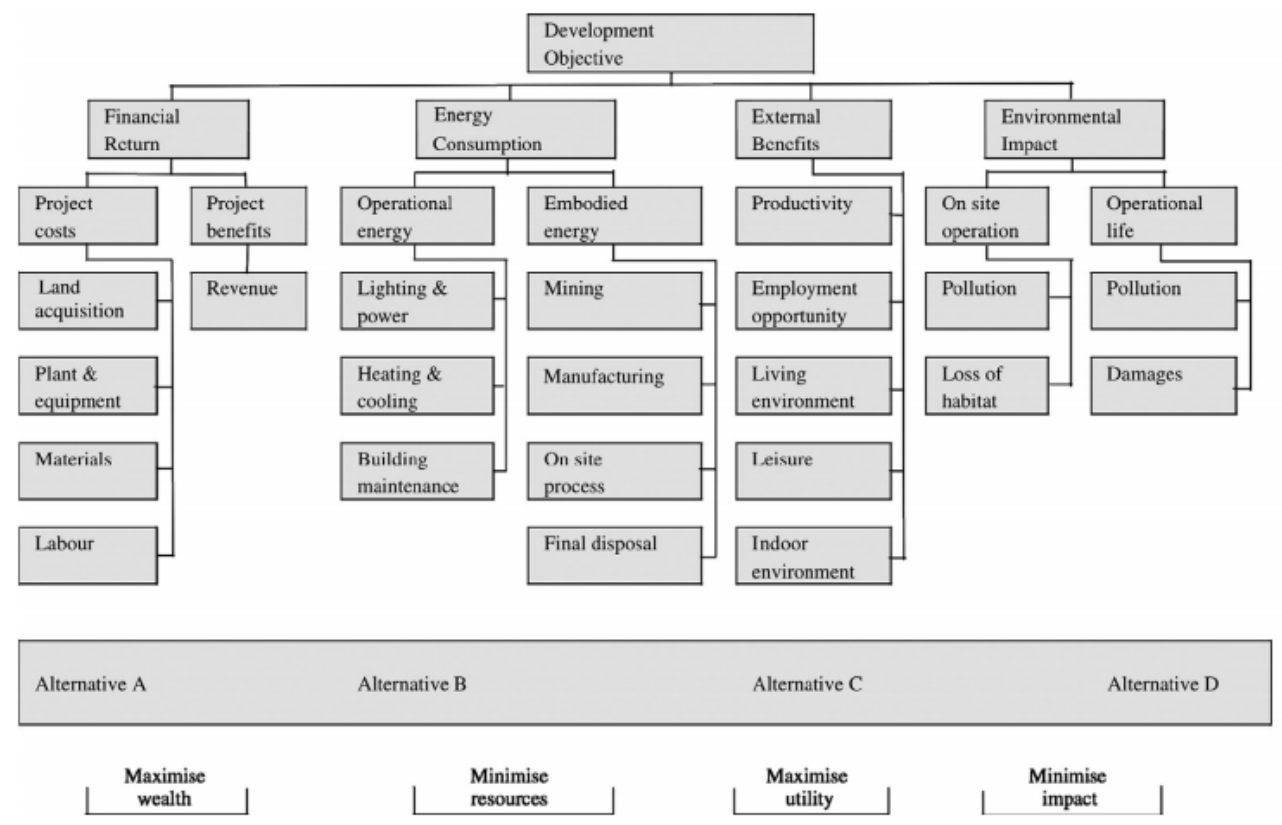

Figure5. Key Factors for Sustainable Developments

Kibert [21] described the major criteria for sustainable construction of green building which include reducing resource consumption, reusing resources, utilization of recycled materials, conservation of the natural environment, removing toxic, considering the economic efficiency, and reinforcing the quality are substantially recommended for ensuring sustainable construction. Ding [22] described the four sustainable key factors for sustainable construction of green building which include reduction of environmental impacts, decreasing the utilization level of resources, increasing utility, and exploiting the economic considerations which is shown in Figure 5. John [23] mentioned that sustainable buildings must be developed based on a clear understanding of the main targets of sustainable developments for a low-carbon future including resource efficiency, energy efficiency (including greenhouse gas emissions reduction), pollution prevention (including indoor air quality and noise abatement), harmonization with environment, integrated and systematic approaches.

Wang [24] evaluated the energy use in a building where he focused six substantial areas which include climate, building envelope, building services, the user's attitudes towards energy consumption and indoor environmental quality. Juan [25] revealed the sustainable energy performance indicators in order to improve the energy performance for reducing the energy consumption. Omer [26] considered the consequences of $\mathrm{CO}_{2}$ and $\mathrm{NO}_{\mathrm{X}}$ emissions on environments as well as sustainability in building energy performance where emphasis has been given on improving indoor environmental quality, cost efficiency and energy efficiency which enable the buildings to reach the acceptable level of performance. From another viewpoint, Chwieduk [27] indicated three main constituents as energy efficient buildings, environmentally responsive buildings and sustainable buildings for reducing the level of energy conservation. Qaemi [28] investigated the substantial criteria for sustainable energy as a basic concept for sustainable developments. Thereby, the respective criteria are deduced to have six main constituents as shown in Table 1.

Table1. Six Main Constituents of a Green building

\begin{tabular}{|c|c|c|}
\hline No. & Criteria & Explanation \\
\hline 1 & Renewable Energy & $\begin{array}{l}\text { Encourage and recognize increasing levels of on-site renewable energy self-supply in order to } \\
\text { reduce environmental and economic impacts associated with fossil fuel energy use. }\end{array}$ \\
\hline 2 & Minimum energy performance & Establish the minimum level of energy efficiency for the proposed building and systems. \\
\hline 3 & $\begin{array}{l}\text { Fundamental commissioning of the } \\
\text { building energy systems }\end{array}$ & $\begin{array}{l}\text { Verify that the building's energy related systems are installed, calibrated and perform according to } \\
\text { the owner's project requirement, the basis of design and construction documents }\end{array}$ \\
\hline 4 & Enhanced commissioning & $\begin{array}{l}\text { Begin the commissioning process early during the design process and execute additional } \\
\text { activities after system performance verification is completed }\end{array}$ \\
\hline 5 & Measurement and verification & Provide for the ongoing accountability of building energy consumption over time \\
\hline 6 & Optimize energy performance & $\begin{array}{l}\text { Achieve increasing levels of energy performance above the baseline in the prerequisite standard to } \\
\text { reduce environmental and economic impacts associated with excessive energy use }\end{array}$ \\
\hline
\end{tabular}


Referring to the essence of sustainable developments, the use of renewable energy is a substantially significant approach towards decreasing the level of energy consumption in buildings. The energy which is derived from the natural resources such as wind, solar, rain, etc; is called renewable energy as one of the most influentially common principles [30]. One of the most commonly used integrated renewable energy systems is the solar-based energy application of photovoltaic systems [29]. Hence, it is proposed to consider utilizing the solar energy based integrated systems for enhancing sustainable energy performances. Usage of different types of renewable energy is illustrated in the Table 2.

In line with the sustainable energy performance of green building, Kumar [30] proposed an integrated solution where green roof is integrated with solar shading devices. Moreover, Jaffal [31] evaluated the effectiveness of green roofs towards indoor enhanced thermal comfort and energy performance of building based on the analysis of a residential case model.

Table2. Versatile Types of Renewable Energy

\begin{tabular}{|c|c|}
\hline Renewable Energy & Description and Benefits \\
\hline $\begin{array}{l}\text { Active solar } \\
\text { Energy }\end{array}$ & $\begin{array}{l}\text { - Convert solar energy into another more useful form of energy. } \\
\text { - This would normally be a conversion to heat or electrical energy. } \\
\text { - Inside a building this energy would be used for heating, cooling, or offsetting other energy usage or } \\
\text { costs. } \\
\text { - The basic benefit is that controls can be used to maximize its effectiveness. } \\
\text { - Photovoltaic solar panels are in this group. }\end{array}$ \\
\hline Passive solar energy & $\begin{array}{l}\text { - In passive solar building design, windows, walls, and floors are made to collect, store, and distribute } \\
\text { solar energy in the form of heat in the winter and reject solar heat in the summer. } \\
\text { - The key to designing a passive solar building is to better take advantage of the local climate }\end{array}$ \\
\hline Wind energy & $\begin{array}{l}\text { Wind power is the conversion of wind energy into a useful form of energy, such as using wind turbines to } \\
\text { make electricity, windmills for mechanical power, wind pumps for water pumping or drainage }\end{array}$ \\
\hline Geothermal energy & Geothermal energy is thermal energy generated and stored in the Earth \\
\hline Fuel cell & $\begin{array}{l}\text { A fuel cell is a device that converts the chemical energy from a fuel into electricity through a chemical } \\
\text { reaction with oxygen or other oxidizing agent. Hydrogen is the most common fuel. }\end{array}$ \\
\hline
\end{tabular}

For ensuring effective sustainable performance of the buildings, many researchers recommended to use ecological sustainable design (ESD) [32]. The term 'ecological' is a terminology related to the interactions between living organisms and physical surroundings. In the context of architecture and the built environment, it reflects the interactions between human, buildings and the environment. Ghaffarian [33] also suggested to use the concept of ecological sustainable design (ESD) which is an approach towards the development of green built environments and must be taken into consideration as one of the main targets of governmental sectors as well as policy makers in the creation of a better and greener environment for the population. Due to the vulnerability of global warming, the integration of ESD into the respective building designs can also play a vital role to mitigate the greenhouse effect. Hypothetically, ESD is considered to be a substantial standard in the modern architecture and construction developments in order to ensure the reduction of negative environmental impacts. Accordingly, the integration of ESD is deemed to become a prominent basis to set criteria for the setting and orientation of the buildings, eco-materials usage, landscape integration design, interior space design, building details and bioclimatic of surroundings [34].

A study by Juan [24] deliberates an operative and effective approach for sustainable development of buildings which indicates five main parameters to be taken into account during the design and construction of buildings. Firstly, it is crucial to make sure that, the building should be properly oriented, considering the location, and characteristics of the land where the building will be located in with a view to its greeneries. Secondly, it is necessary to adopt wastewater technological approaches where potable water is used by recycling and reusing, including harvested rainwater, storm water, and gray water. Thirdly, it is important to consider the energy efficiency of the building with regards to its energy performance, thermal comfort, HVAC systems and innovatively integrated energy saving technologies. Fourthly, it is essential to make a healthy, pleasant and productive work environment which offer the best possible conditions in terms of indoor air quality, ventilation, thermal comfort, access to natural ventilation and day lighting. Lastly, it is required to consider the significant role of material suitability and the application of recycled materials.

A new ranking system regarding sustainable energy performances was studied by Mwasha [10] which is shown in the Figure 6. The findings represent that the level of energy consumption, conservation is the top-ranked parameter with the highest level of importance index followed by operational energy, energy subsidies and policies. 


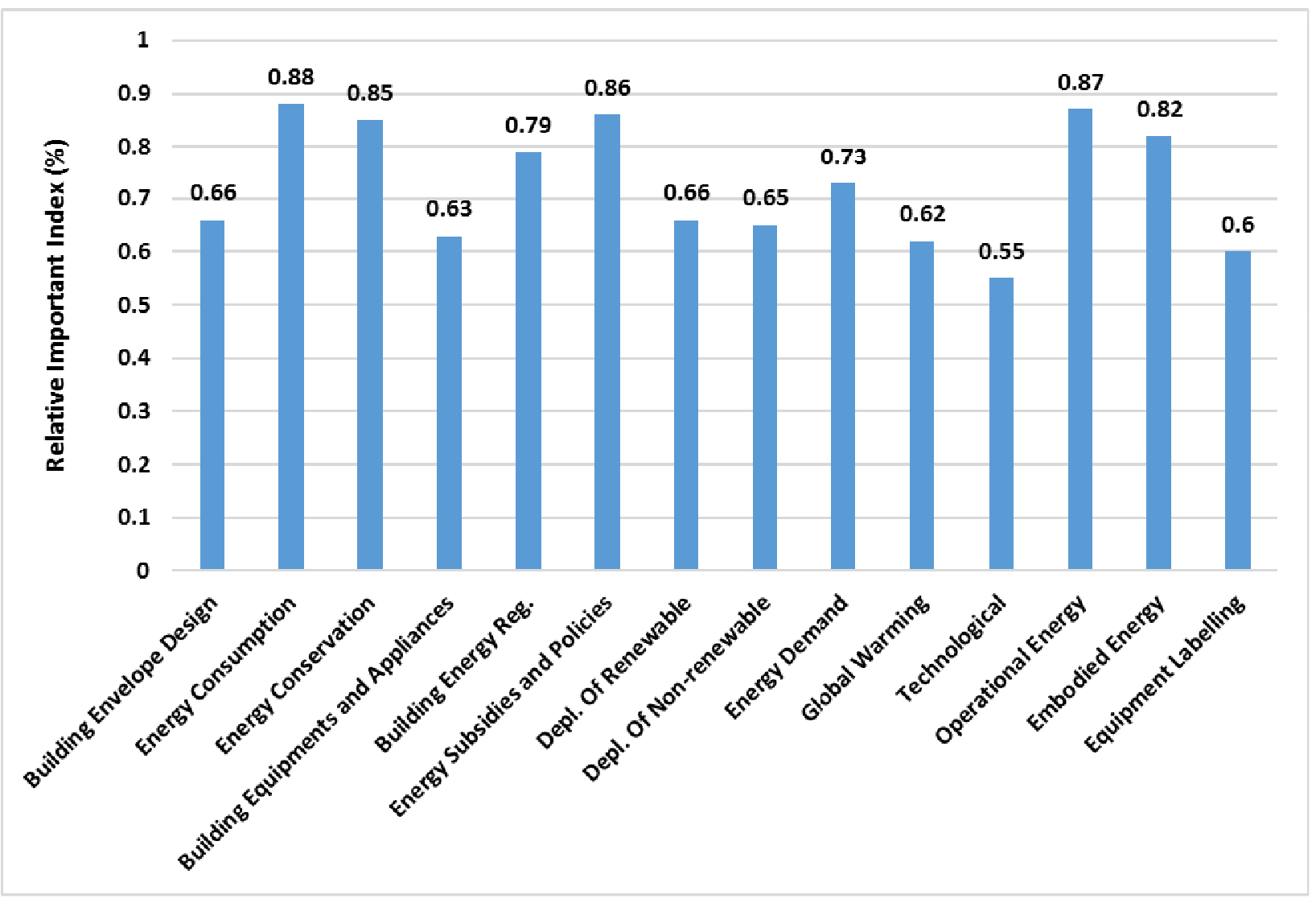

Figure6. Energy Efficiency Criteria

\section{Benefits of Green Buildings}

Based on the several thousands of green buildings designed and operated over the last couple of decades, there is increasing evidence around the world that green buildings deliver a suite of economic, social and environmental benefits that conventional buildings do not. Buildings have the potential to reduce energy consumption by 75 percent, contributing to 20 percent reduction in the world's total energy needs, improving the quality of life, creating over a million jobs and reducing pressure on energy price [35].

Table3. Benefits of Green Buildings [14]

\begin{tabular}{|c|c|}
\hline Benefits & Explanation \\
\hline Capital cost saving & $\begin{array}{l}\text { The approach of green building design helps in substantial cost saving. For example, green building is built } \\
\text { considering the local climate condition can cut down the need for heating/cooling substantially, thus helping } \\
\text { to downsize the HVAC system, including the bulky mechanical equipment and ductwork; the space saved } \\
\text { can be sold or leased to earn additional revenue. For example, the first LEED-certified commercial building } \\
\text { in China was the TaiGe serviced apartments in Shenzen which was established in } 2004 \text { has performed } \\
\text { satisfactorily by cutting down a significant amount of energy. The effectiveness and potentiality saves } 75 \\
\text { percent of lighting power and } 50 \text { percent of air conditioning power consumption while providing the same } \\
\text { visual and thermal comfort [36]. }\end{array}$ \\
\hline $\begin{array}{l}\text { Better performance and operational } \\
\text { cost savings }\end{array}$ & $\begin{array}{l}\text { The bioclimatic architecture along with the use of insulation, high efficiency equipment and appliances can } \\
\text { guarantee substantial operational cost savings (e.g. typically } 30 \text { to } 50 \text { percent lower energy and water bill } \\
\text { and waste disposal costs, along with reduced carbon footprint from energy savings). This is particularly } \\
\text { relevant in the context of high fossil fuel and prices which are unlikely to come down in the future. }\end{array}$ \\
\hline Reduced construction time schedule & $\begin{array}{l}\text { An integrated and teamwork approach to designing is adopted while constructing a green building, resulting } \\
\text { in minimized conflicts during the construction phase, allowing the project to be commissioned ahead of } \\
\text { schedule. Time saved on the project allows the builder to lower the cost and gain higher benefit. }\end{array}$ \\
\hline
\end{tabular}




\begin{tabular}{|c|c|}
\hline Benefits & Explanation \\
\hline $\begin{array}{l}\text { Improved marketability and } \\
\text { enhanced value }\end{array}$ & $\begin{array}{l}\text { In order to improve the marketability, attracting and retaining employees, and building corporate image, } \\
\text { green buildings can be considered as distinct products. As such buildings are conceived to provide an } \\
\text { improved indoor environment and improved productivity of employees, the scope for selling or renting them } \\
\text { is enhanced. }\end{array}$ \\
\hline Higher future value of property & $\begin{array}{l}\text { Green buildings guarantee lower operating costs, rendering them more competitive for sale or to be leased at } \\
\text { a premium. According to American and British studies, the asset value of a building can increase by } 6-15 \\
\text { percent if it is covered by trees. Moreover, clients see better future prospects of selling the acquired } \\
\text { properties. }\end{array}$ \\
\hline Reduced advertising costs & $\begin{array}{l}\text { Because of their superior design and ecological contribution, green buildings attract media attention and get } \\
\text { free publicity, thus helping them to cut down the expenditure on promotional advertising. }\end{array}$ \\
\hline Reduced liability and risk & $\begin{array}{l}\text { As insurance companies get a better aware of the positive contribution of green buildings in terms of lower } \\
\text { operating costs and better indoor environment, they are likely to link lower insurance premium to green } \\
\text { buildings. }\end{array}$ \\
\hline
\end{tabular}

\section{Barriers to the Propagation of Green Building}

The challenges and barriers confronting the greening of buildings are different for industrialized and developing countries. Industrialized countries have a head-start in addressing challenges and overcoming barriers but they are overburdened by the predominance of existing building stock that are to be retrofitted and converted into green assets. On the other hand, developing countries have a huge need to construct new buildings but are lagging behind in adopting suitable policies to tackle various barriers to green building. In addition to the typical economic and financial challenges, there is also a huge vacuum in terms of awareness and capacity to deliver. There is urgency for developing countries in Asia to hasten policy efforts in order to achieve the paradigm change needed to make new buildings sustainable and avoid the huge financial burden of retrofitting them later [14].

Understanding the different barriers that hinder the growth of green buildings and community is extremely important before any action or measure can be taken to bring in the changes. While many believe that a major barrier to green buildings is the cost, this is not true in most cases. In the urban context, it is the land price that makes the difference. In central urban areas such as Singapore, Hong Kong and Shanghai, land prices can represent up to 75 percent of the total cost for a building, so adding a few percent of building cost would be quite marginal to the total [38]. Thus barriers are more linked to lack of policies, understanding of the crucial issues, business models, markets, know-how and technologies, commitment, etc. The Carbon Trust classifies the barriers into four categories, as shown in the Table 4.

Table4. Barriers Hindering the Penetration of Energy-Efficiency in the Building Sector [37]

\begin{tabular}{|c|c|c|}
\hline Barriers Categories & Definition & Example \\
\hline $\begin{array}{l}\text { Financial costs/ } \\
\text { Benefits }\end{array}$ & $\begin{array}{l}\text { Ratio of investment cost to value of } \\
\text { energy savings }\end{array}$ & $\begin{array}{l}\text { - Higher upfront costs for more efficient equipment } \\
\text { - Lack of access to financing } \\
\text { - Energy subsidies } \\
\text { - Lack of internalization of environmental, health and other external cost }\end{array}$ \\
\hline $\begin{array}{l}\text { Hidden costs/ } \\
\text { benefits }\end{array}$ & $\begin{array}{l}\text { Cost or risks (real or perceived) that are } \\
\text { not captured directly in financial flows }\end{array}$ & $\begin{array}{l}\text { - Costs and risks due to potential non-compatibilities, performance risks, } \\
\text { transaction costs, etc. } \\
\text { - Poor power quality, particularly in some developing countries }\end{array}$ \\
\hline Market failures & $\begin{array}{l}\text { Market structures and constraints that } \\
\text { prevent the consistent trade-off between } \\
\text { specific energy-efficient investment and } \\
\text { the energy-saving benefits }\end{array}$ & $\begin{array}{l}\text { - Limitations of the typical building design process } \\
\text { - Fragmented market structure } \\
\text { - Landlord/tenant split and misplaced incentives } \\
\text { - Administrative and regulatory barriers (e.g. in the incorporation of distributed } \\
\text { generation technologies) } \\
\text { - Imperfect information }\end{array}$ \\
\hline
\end{tabular}




\begin{tabular}{lll}
\hline Barriers Categories & Definition & Example \\
\hline & $\begin{array}{l}\text { Behavioral characteristics of } \\
\text { individuals and organizational } \\
\text { characteristics of companies that } \\
\text { hinder energy efficiency } \\
\text { technologies and practices }\end{array}$ & $\begin{array}{l}\text { - Tendency to ignore small opportunities to energy conservation } \\
\text { Behavioral constraints }\end{array}$ \\
\end{tabular}

\section{Recommendations to Overcome the Barriers to Green Building Development}

Some policies have been initiated and implemented by the government around the world to address country-specific barriers to the propagation of green buildings. Appropriate policy instrument is needed to be addressed corresponding to each type of barrier encountered. In this article, the policy measures are classified into five distinct categories [14].

\subsection{Awareness and Sensitization}

The first barrier which is needed to address is the lack of awareness and understanding about the potential benefits that can be accrued from green buildings. Creating awareness and/or sensitization requires identification of the target groups along with individuals. The target groups in this case are not only the private players such as building developers and users but also politicians as well as planners, policy makers, and economic players. A survey by IEA (2010) identified that the barriers towards development of energy efficient buildings where lack of information and low awareness has been cited most. Other frequently cited barriers included low energy prices, difficulty in accessing affordable financing and lack of policy implementation capacity [8].

\subsection{Innovative Financing}

Investment in green building does not necessarily generate revenue but leads to operational cost reduction is not well recognized by financial institutions. On one hand, there is a need to create awareness among financial institutions that green buildings can actually render the loan repayment more attractive, especially in the unstable environment of sudden energy price hikes. At the same time, it needs strong advertisement to promote green building investment to address the genuine problem of the target beneficiaries to invest in green buildings. This is an important aspect to take into consideration in order to avoid market distortions because green technological solutions that are intended to be financed should make business sense.

\subsection{Market Transformation}

There are various ways to boost up the market for green building development. Generally, the private sector is most active in the marketplace and the government does not have much of a role to play there. However, it's the government whose initiate and intervention is required most to trigger the market transformation and make green buildings more affordable. In this step, it is essential to favor public and private cooperation so that the private sector participates actively in the program implementation and the limited public funding is leveraged by private sector investment to accelerate the process of market transformation. It is a relatively inexpensive mechanism for stimulating innovation and competition among potential manufacturers by guaranteeing higher market share for their products.

\subsection{Advice and Capacity Building}

Lack of knowledge and inadequate capacity of the target groups to adopt green building technologies and practices always hinder to the growth of green building development. Green features invariably add to the costs and entail delays in project execution which is traditionally assumed by most of the people. However, in reality, it's not always hold true. Therefore, it is necessary to assist important stakeholders to upgrade their knowledge of green building design process and help them to understand the multiple benefits of making an investment not on first-cost alone but on the basis of life-cycle analysis. Another type of support may be in the form of training and capacity building of targeted players so that they are capable of making their own decision and taking appropriate steps towards the implementation of suitable solutions..

\subsection{Legislation and Regulation}

Laws and regulations can be in the form of energy codes, labels, and standards. This guideline may serve various purposes including providing the required information to the intended beneficiary, ensuring a minimum guarantee of the green performance of the equipment or product, or even eliminating very low-quality products from the market. Setting of appropriate standards for new products or construction projects can play a crucial role in the context of developing countries in Asia that have high demand for new buildings and facilities associated with the rapid economic growth.

\section{Conclusion}

The detailed analytical review shows that the sustainable energy performance of green buildings has played a vital 
role to reduce the energy consumption. Besides, sustainable buildings hold some of the most profitable means of abating climate change. With the present-day methods of design, construction, use and maintenance, large quantities of resources such as materials, energy and money are consumed. Green building practices strive for integral quality in a very broad way, including economic, social and environmental performance. Rational use of resources and appropriate management of building stocks contributes to saving scarce resources, reducing energy consumption and improving the environmental quality. Sustainable buildings can achieve cost reductions because of the lower need for lighting, ventilation, heating and cooling, they may incur slightly higher capital costs because of the additional features and systems incorporated in these buildings, such as on-site energy generation, rainwater harvesting or wastewater recycling, etc. However, the marginally higher investments guarantee the generation of several-fold higher life-cycle savings. Further benefits can be in the form of better thermal, visual and acoustic comfort, improved air quality and human health, enhanced performance and productivity. Sustainable landscaping and adoption of bioclimatic features can help the buildings to improve the urban microclimate and air quality. On the whole, green buildings have considerable potential benefits for their owners, users, the environment, and the society in general. Moreover, with a view to the current challenges and barriers, the study demonstrates that it is substantially crucial to innovate and develop efficient energy solutions associated with green buildings for addressing the future energy demands. Besides, corresponding to each type of barrier encountered, the study also suggests the possible policy options is needed to overcome the barriers.

\section{References}

[1] IPCC, Climate Change (2007). Mitigation of climate change. "Contribution of Working Group III to the Fourth Assessment Report of the Intergovernmental Panel on Climate Change", Cambridge University Press, Cambridge, New York, 2007

[2] WBCSD, "Energy efficiency in buildings: Transforming the market", World Business Council for Sustainable Development, Geneva, 2008

[3] IEA (International Energy Agency), "World Energy Outlook 2008: Global Energy Trends to 2030, Chapter 8" - Energy use in cities, OECD/IEA Publication, 2008

[4] WBCSD, "Energy efficiency in buildings: transforming the market", World Business Council for Sustainable Development, Geneva, 2011

[5] McKinsey \& Company, "Pathways to a Low-Carbon Economy", Version 2 of the Global Greenhouse Gas Abatement Cost Curve, 2009

[6] L. Starke, "State of the World - Our Urban Future", Chapter 5: Energizing cities, 24th Edition, Earthscan, Worldwatch Institute, 2007
[7] M. Betts and S. Farrell, "Global construction 2020: A global forecast for the construction industry over the next decade", Global Construction Perspectives and Oxford Economics, London, 2009

[8] IEA (International Energy Agency), "Energy performance certification of buildings", OECD/IEA Publication, 2010

[9] UNEP (United Nations Environmental Programme), "Buildings and climate change, status, challenges and opportunities”, UNEP Publication ISBN:9280727958, 2007

[10] A. Mwasha, R.G. Williams, J. Iwaro, "Modeling the performance of residential building envelope: The role of sustainable energy performance indicators", Energy and Buildings, vol 43(9), pp. 2108-17, 2011

[11] A. Joelsson A, L. Gustavsson, "District heating and energy efficiency in detached houses of differing size and construction" Applied Energy, vol 86(2), pp.126-34, 2009

[12] COAG (Council of Australian Governments). "National Strategy on Energy Efficiency”. Canberra, 2009

[13] McKinsey \& Company, "Pathways to a Low-Carbon Economy, Version 2 of the Global Greenhouse Gas Abatement Cost Curve", 2009

[14] B. Mohanty. "Green Buildings: Features, Technologies and Policies", Hand-out for the Course ED729020: Rational Use of Energy in Buildings August Semester 2011

[15] C. Thormark, "The effect of material choice on the total energy need and recycling potential of a building. Building and Environment", vol 41 (8), pp. 1019-1026, 2006

[16] UNEP (United Nations Environmental Programme). "Green Economy: Pathways to Sustainable Development and Poverty Eradication", Advance copy online release, accessed on 19 October 2011, http://www.unep.org/GreenEconomy/Portals/93/documents/ Full_GER_screen.pdf

[17] A. Ghaffarian Hoseini, R. Ibrahim, MN. Baharuddin, "Creating green culturally responsive intelligent buildings: Socio-cultural and environmental influences", Intelligent Buildings International, vol 3(1), pp. 5-23, 2011

[18] N.W. Alnaser, R Flanagan, WE Alnaser. "Model for calculating the sustainable building index (SBI) in the kingdom of Bahrain". Energy and Buildings, vol 40, pp. 2037-43, 2008

[19] N. Aste, R.S. Adhikari, M. Buzzetti, "Beyond the EPBD: The low energy residential settlement Borgo Solare". Applied Energy, vol 87, pp. 629-42, 2010

[20] N. Aste, C.D. Pero, "Impact of domestic and tertiary buildings heating by natural gas in the Italian context". Energy Policy, vol 47, pp. 164-71, 2012

[21] C. Kibert, "Sustainable Construction: Green Building Design and Delivery" New Jersey: John Willey \& Sons, Inc; 2007.

[22] G.K.C. Ding. "Sustainable construction - The role of environmental assessment tools". Journal of Environmental Management, vol 86, pp. 451-64, 2008

[23] G. John, D. Clements-Croome, G. Jeronimidis. "Sustainable building solutions: a review of lessons from the natural world. Building and Environment”, vol 40, pp. 319-28, 2005 
[24] S. Wang S, C. Yan C, F. Xiao F. "Quantitative Energy Performance Assessment Methods for Existing Buildings". Energy and Buildings, vol 55, pp. 873-88, 2012

[25] Y. Juan, P. Gao, J. Wang, “A hybrid decision support system for sustainable office building renovation and energy performance improvement", Energy and Buildings, vol 42, pp. $290-7,2010$

[26] A.M. Omer, "Energy, environment and sustainable development. Renewable and Sustainable Energy Reviews", vol 12(9), pp. 2265-300, 2008

[27] D. Chwieduk, "Towards sustainable-energy buildings", Applied Energy, vol 76, pp. 211-7, 2002

[28] M. Qaem, G. Heravi, "Sustainable Energy Performance Indicators of Green Building in Developing Countries". Construction Research Congress 2012 (C) ASCE, US 2012:1961-70

[29] L.L. Kazmerski, "Solar Photovoltaic Technology: No Longer an Outlier", Comprehensive Renewable Energy, pp. 13-30, 2012

[30] R. Kumar, S.C. Kaushik. "Performance evaluation of green roof and shading for thermal protection of buildings". Building and Environment 2005, vol 40, pp. 1505-11, 2005.

[31] I. Jaffal, S. Ouldboukhitine, R. Belarbi. "A comprehensive study of the impact of green roofs on building energy performance". Renewable Energy, vol 43, pp. 157-64, 2012

[32] L. Shi, M.Y.L. Chew. A review on sustainable design of renewable energy systems. Renewable and Sustainable Energy Reviews, vol 16, pp. 192-207, 2012

[33] A. GhaffarianHoseini, "Ecologically sustainable design (ESD): theories, implementations and challenges towards intelligent building design development", Intelligent Buildings International, vol 4(1), pp. 34-48, 2012

[34] S. Fazlic, "Design strategies for environmentally sustainable residential skyscrapers". CTBUH 8th world congress, Dubai, 2008; $1-11$

[35] Wen Hong et al. (2007). Building energy efficiency: why green buildings are key to Asia's future, Edited by Margarethe P. Laurenzi, The Asia Business Council

[36] Carbon Trust (2005). The UK Climate Change Programme: potential evolution for business and the public sector. Technical Report

[37] C. Kornevall, "Green Week Asia - not so green"; http://wbcsd.typepad.com/eeb/2007/11/last-week-took-.html, November 2007

[38] J. Clerk Maxwell, "A Treatise on Electricity and Magnetism", 3rd ed., vol. 2. Oxford: Clarendon, 1892, pp.68-73. 